\title{
Synoptic Analyses of the Precipitation in Nepal in 1974*
}

\author{
Chotaro Nakajima**, Madan L. Shrestha*** and M.B. Basnyat***
}

\begin{abstract}
A synoptic analyses were done of the precipitation in August and December in 1974. Types of precipitation in this August were much different between those in the northern coast of the Bengal Bay, the plain and high mountain area in Nepal. The monsoon currents come from the equatorial region, but the possibility of the intrusion of the monsson wind into the mountain area is affected by the behaviour of the westerly current in middle latitudes. When the Tibetan High move to the north, the monsoon wind easily flows into the Himalayan region. The position of the trough line of the wave in middle latitudes is also important. In the winter season, the precipitation in the plain area of Nepal is of the showery type, but rainfall in the high mountain area is relatively continuous. The relation between the precipitation and the behavior of the middle latitude upper level wind is more intimate in the winter season. To understand the precipitation in Nepal, the interaction of the middle and the low latitude atmospheric circulation, and also the local behavior of the mountain and valley winds in relation to the orographic conditions must be studied.
\end{abstract}

\section{Introduction}

There are many reports of the synoptic analysis of the precipitation in India, but there are few such reports of the synoptic analysis in TibetanHimalayan region. This is mainly due to the lack of the meteorological data in this region and the difficulty of the synoptic analysis in such a region with complicated orographic conditions.

However, there are some literatures on the climate of Nepal. Hagen (1961) described on the climatic difference between the mountain and basin areas. Kraus (1960) explained the relation between the general atmospheric circulation and the climate of Nepal. He showed many figures of the annual variations of the meteorological elements in Nepal and attempted to classify the types of the climate in detail. Malla (1968) made a general review of the climate of Kathmandu and also discussed on the climatic change.

According to Koteswaram (1973) western distur-

* Glaciological Expedition to Nepal, Contribution No. 14

** Disaster Prevention Research Institute, Kyoto University, Uji-shi, Kyoto 611.

*** Meteorological Service, Dep. of Irrigation, Hydrology and Meteorology, Ministry of Food, Agriculture and Irrigation, Kathmandu, NEPAL bances move along the southern foot of the Himalayas 6-7 times in a winter and 2-3 times in a spring and the intensities of these disturbances are important to forecast the intensities of the precipitation in the Himalayas. Thus, he made a review of the typical change of the synoptic conditions in this area. Osada (1972) made weather forecasting for the Japanese Mount Everest Expedition 1969-1970 by upper air analyses and reported the many interesting synoptic characters in this region. Oi (1969) also made a three dimensional analysis of the South Asia for the weather forecasting in this region. Raghavan (1972) discussed on the weather analysis and forecasting over the Indo-Tibetan Region using $500 \mathrm{mb}$ charts in the middle latitudes.

In this paper, we make some case studies on the synoptic analysis of the precipitation in Nepal.

\section{Synoptic analysis of the precipitation in August 1974}

Fig. 1 shows the daily precipitation during the period from July 15 to August 20, 1974 at Calcutta (India) and at Kathmandu, Hidden Valley and Lhajung (Nepal). There are many rainy days at these stations in this season, but the total amounts of precipitation are relatively small at Hidden Valley and Lhajung in the mountain area, in comparison with that of 

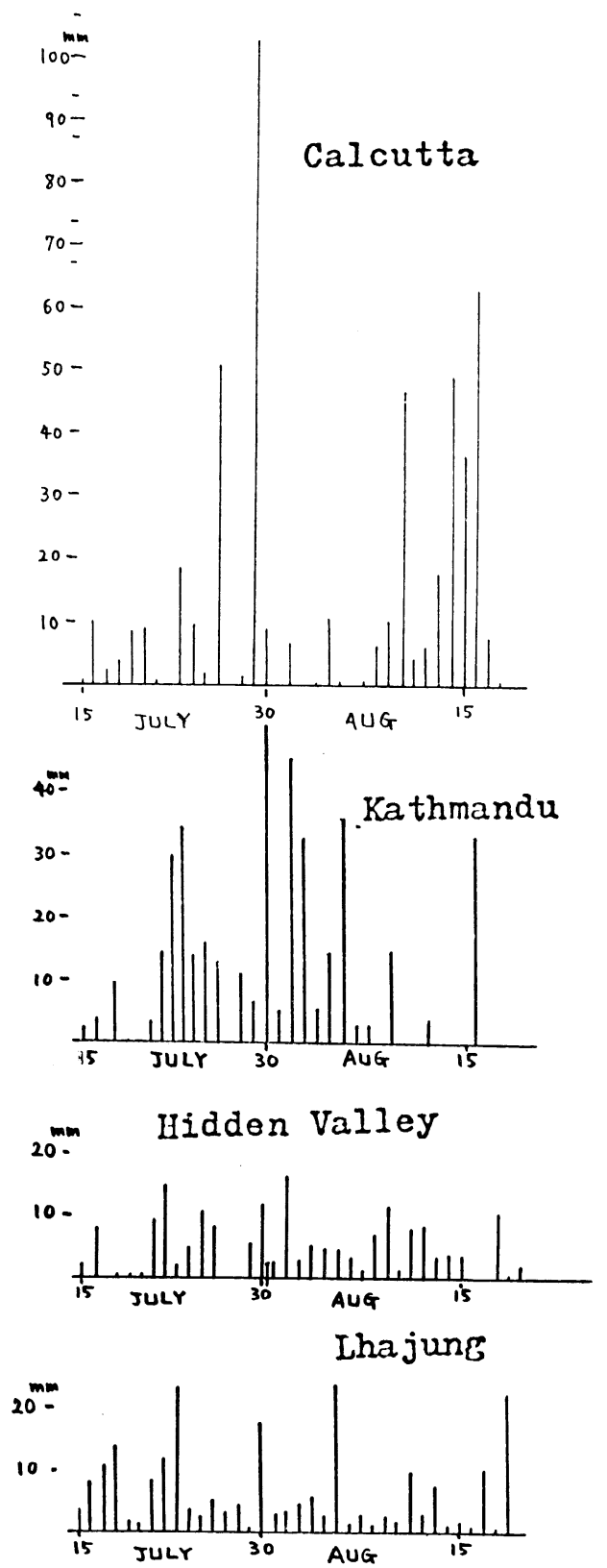

Fig. 1. Daily Amount of Precipitation from July 15 to August 20, 1974.

Kathmandu in central Nepal.

The variation of the amount of daily precipitation is very large at Calcutta near the coast of the Bay of Bengal in comparison with that in the mountain area in Nepal. In Fig. 2 of $T$. Yasunari (1976 a), we can see that drizzle occurred on many days in the mountain area, but drizzle does not contribute much to an increase of the

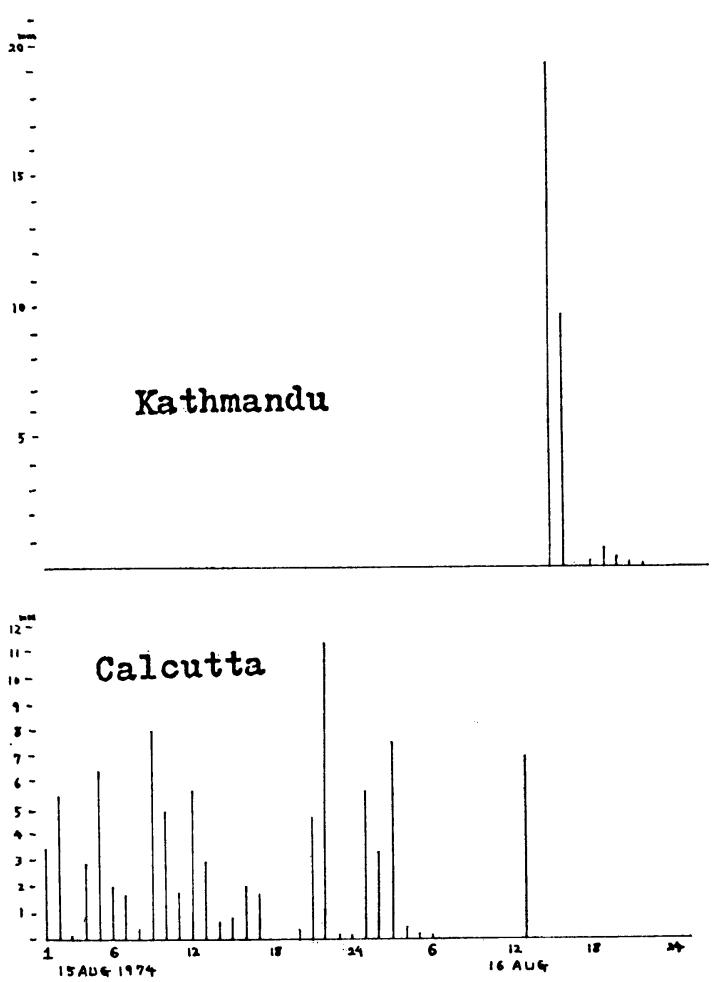

Fig. 2. Hourly Amount of Precipitation from $1 \mathrm{~h}$ on August 15 to $24 \mathrm{~h}$ on August 16.

total amount of precipitation. But, relatively many locally heavy rains occurred in the lower part of Nepal. Table 1 shows the daily amounts of precipitation at the various stations in Nepal for August 13-19, 1974. In this table, the name of the station is written by the station number, and the locations are shown in Fig. 5, of T. Yasunari (1976 b). From this table, it can be seen that the locally heavy rainfall is mainly at relatively lower elevations. This locally heavy rainfall contributes to the increase of the monthly amount of the precipitation at these lower stations.

Fig. 2 shows the hourly amounts of precipitation during the period from $01 \mathrm{~h}$ on August 15 to $22 \mathrm{~h}$ on August 16 at Kathmandu and Calcutta. The precipitation at Kathmandu was concentrated in a short period and that at Calcutta occurred continuously. This means that the precipitation in Kathmandu was due to showers and that in Calcutta was due to continuous rainfall.

Thus, in the plain area in Nepal, the intensity of the rainfall is strong, but in the mountain area, the intensity of the rainfall becomes weak 
Table 1. Daily amount of precipitation $(\mathrm{mm})$ in the various stations in Nepal during August, 13-18, 1974.

\begin{tabular}{|c|c|c|c|c|c|c|c|}
\hline $\begin{array}{l}\text { Station } \\
\text { Number }\end{array}$ & 13 & 14 & 15 & 16 & 17 & 18 & 19 \\
\hline 0101 & 8.8 & 6.0 & $\mathrm{~T}$ & - & - & - & \\
\hline 0104 & 8.4 & 4. 3 & 1. 2 & 0.6 & 0.2 & 4. 3 & 25.5 \\
\hline 0201 & 0.4 & - & 4. 4 & 2. 4 & - & 2. 2 & 2.0 \\
\hline 0202 & 4. 0 & - & $\mathrm{T}$ & 4. 0 & - & 28.3 & 5.0 \\
\hline 0203 & 22.0 & - & - & - & - & - & 28. 2 \\
\hline 0205 & 10.2 & $\mathrm{~T}$ & 2.4 & 0.8 & - & 4. 0 & 22.2 \\
\hline 0306 & 26,4 & 18. 8 & 10.6 & 16.4 & - & 21.6 & 16.6 \\
\hline 0308 & - & 0.8 & 1. 6 & 3.4 & 0.8 & 5.2 & 2. 4 \\
\hline 0402 & 17. 0 & 13. 2 & - & - & - & 0.8 & 10.0 \\
\hline 0404 & - & - & - & - & - & - & 19.8 \\
\hline 0501 & - & - & 16.0 & 2. 0 & - & - & - \\
\hline 0504 & $\mathrm{~T}$ & 6.2 & 4. 2 & 1.8 & - & 4.4 & 1. 2 \\
\hline 0505 & - & 13. 6 & 0.2 & - & - & 3.1 & 0.5 \\
\hline 0601 & 6.0 & - & - & - & 2.2 & 3. 0 & 5.2 \\
\hline 0604 & 3.0 & 2.0 & - & - & - & 6.0 & 2.5 \\
\hline 0605 & 0.2 & 21.6 & 1. 0 & 5.6 & $\mathrm{~T}$ & $\mathrm{~T}$ & 29.2 \\
\hline 0607 & 2.4 & 8.6 & - & $\mathrm{T}$ & 5.0 & 13. 2 & 2.6 \\
\hline 0608 & 1. 2 & - & - & 4. 0 & 0.4 & 2.8 & - \\
\hline 0609 & - & 7. 4 & 1. 2 & - & - & - & 9.6 \\
\hline 0802 & 2. 4 & 76.4 & 6.0 & - & 31.4 & - & 3. 6 \\
\hline 0808 & 16.8 & $\mathrm{~T}$ & - & - & - & - & - \\
\hline 0809 & - & 1.0 & - & 0.7 & 0.4 & 1.0 & - \\
\hline 1001 & - & - & - & - & 1. 5 & - & - \\
\hline 1004 & - & 1.0 & $\mathrm{~T}$ & - & 1.0 & 9.0 & 9.0 \\
\hline 1016 & 64.0 & 7.6 & 4.4 & 36.2 & 12.0 & 10.1 & 12.1 \\
\hline 1030 & - & 0.2 & - & - & 32.8 & - & - \\
\hline 1102 & 17.0 & 12.5 & 6.0 & 4.5 & 6.0 & 47. 0 & 15. 2 \\
\hline 1218 & 4. 4 & 4. 2 & 2.4 & 4.0 & 4.4 & 10.3 & 6.3 \\
\hline 1219 & - & 4. 4 & 4.8 & 9.0 & $\mathrm{~T}$ & $\mathrm{~T}$ & 36.2 \\
\hline
\end{tabular}

(drizzle) and rainfall occurres more frequently. high latitudes to the Bay of Bengal approximately In mountain areas, drizzle occurs every day ac- along the $90^{\circ} \mathrm{E}$ meridian corresponding to the companied by valley wind. When synoptic disturbances approach, the drizzles change to heavier rainfall.

Fig. 3 shows the surface weather maps on August 15, 16 and 29,30 as typical pressure pattern for this area. In the monsoon season, cyclones frequently appear over northern Pakistan and over the coast of the northern part of the Bay of Bengal. Fig. 4 shows 5-day mean $500 \mathrm{mb}$ contours maps indicated by the deviation from the [normal year, where the shaded area has a positive deviation and the non-shaded area has a negative deviation. In the mean maps for August 14-18, the negative area extends from the surface low in the Bay of Bengal on August 15, 16. However, in the case of August 29-September 2 , the axis of the negative area shifts westward corresponding to the surface low in northern Pakistan on August 29 and 30. These negative areas are caused by the deep trough in the westerly wind in middle latitudes. As can be seen in this example, even in the monsoon season the westerly wave in middle latitudes sometimes affects the weather in the northern parts of India, in Nepal and in Pakistan. Large scale surface cyclones seldom appear in Nepal in the monsoon season, but indirect effects of the cyclones in India or Pakistan may affect the atmospheric 

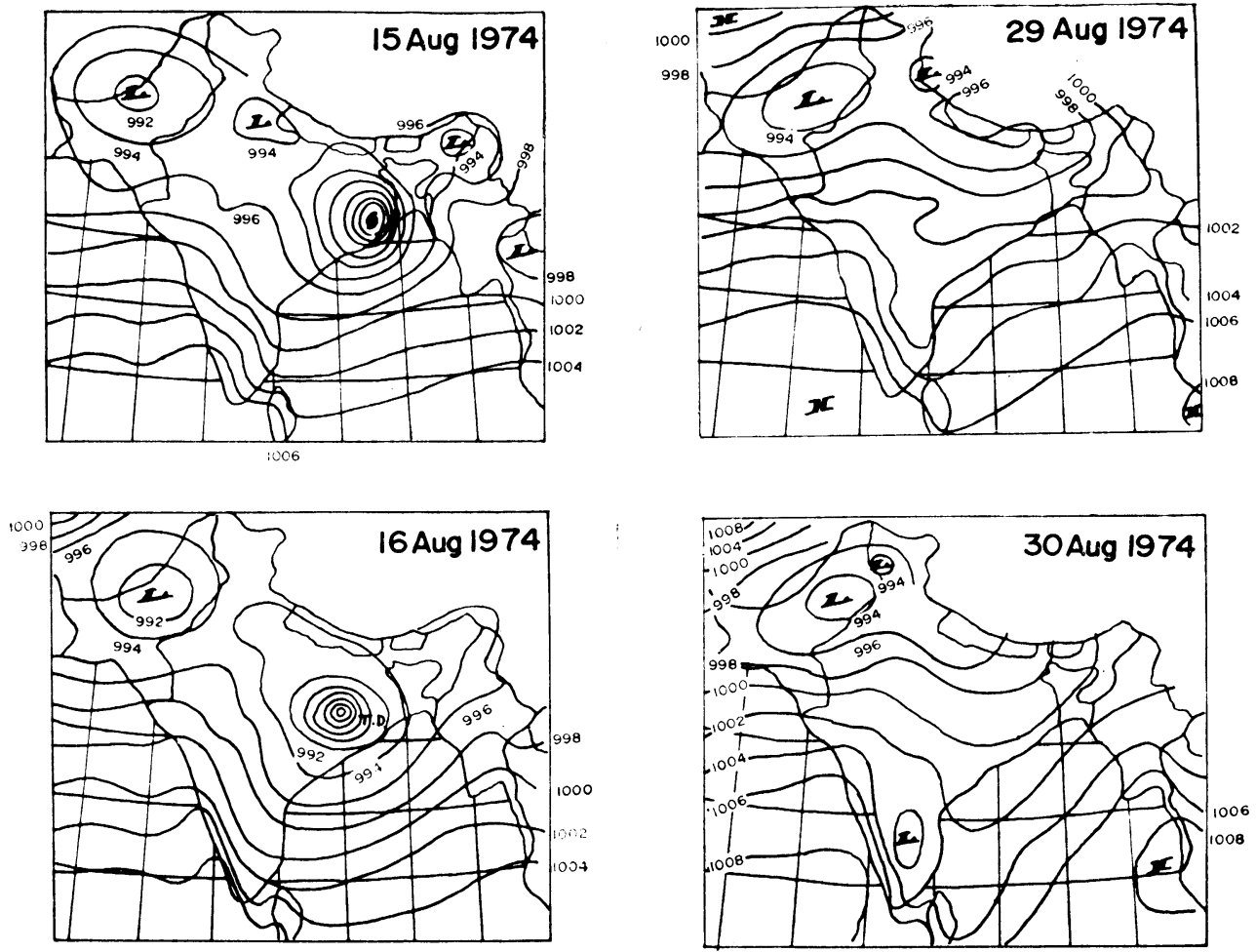

Fig. 3. Surface weather maps on August, 15, 16 and 29, 30, 1974.

stability over Nepal.

\section{Synoptic analysis of the precinitation in December 1974}

In the winter season, the rainfall distribution is much different than in summer, and it is almost completely dry in northern India. In Nepal, the amount of precipitation in the mountain area is the almost same as that in the plain area, but in some cases, the amount in the mountain area is larger. When a deep trough in the westerly current in middle latitudes extends to this area, showerly rainfall or snowfall occurs in this area.

In Fig. 2 of T. Yasunari (1976 a), it can be seen that there was almost no precipitation from Octover 25 to December 15 in 1974, but snowfall occurred during the period December 15-17 after a long dry period. Fig. 6 shows the surface weather maps of December 15 and 17, 1974. On December, 15, a low of $1010 \mathrm{mb}$ can be seen in the northern part of India, and this low moved eastward and arrived over the western part of Nepal on December 17 after weakening. Fig. 5 shows the $500 \mathrm{mb}$ weather map at 12 GMT on December 17, 1974. The developed blocking pattern over the Asiatic Continent and one branch of the jet stream deviates to the north and the other branch of the jet stream deviates to the south; the confluence of these branches near Japan causes a strong jet stream to flow over Japan. In this map, cold air covers both the northern part of the Indian peninsula and Japan. This is an example of the intimate relationship between the weather conditions in Nepal and those in Japan.

Table 2 gives the meteorological data at 5 stations for December 14-17, $1974 . \quad$ New Delhi (India) is located to the west of Kathmandu, and Kathmandu $(1300 \mathrm{~m})$ is in the central part of Nepal; Shyanboche Air Port $(3850 \mathrm{~m})$ is near Namche Bazar; Thanboche $(3870 \mathrm{~m})$ is located between Shyanboche and Lhajung $(4550 \mathrm{~m})$. At these meteorological stations precipitation occurred during December 15-17. Total amounts of precipitation during these three days are 18.0 $\mathrm{mm}$ (Shyanboche), $10.8 \mathrm{~mm}$ (Kathmandu), $8.2 \mathrm{~mm}$ (Lhajung), $6.5 \mathrm{~mm}$ (New Delhi) and $6.0 \mathrm{~mm}$ 

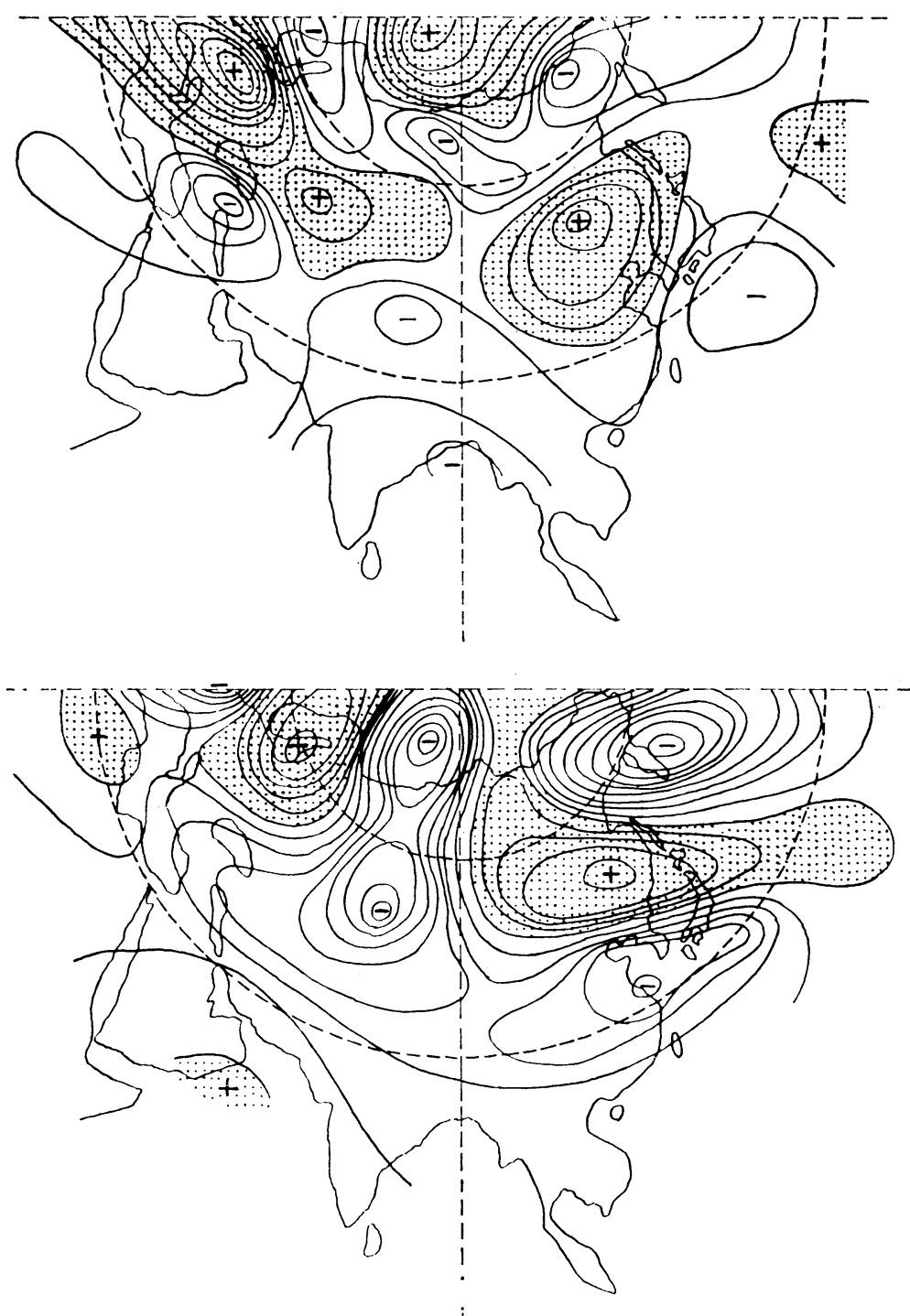

Fig. 4. Five-days mean $500 \mathrm{mb}$ contours (deviation from normal year). Shaded area is positive deviation area and non-shaded area is negative deviation area. Intervals of contour lines are $20 \mathrm{~m}$. Upper: August 14-18, 1974, Lower: August 29-September 2, 1974.

(Thanboche) respectively. The maximum value was $18.0 \mathrm{~mm}$ at Shyanboche. The precipitation was in the form of rainfall at New Delhi and Kathmandu, but snowfall in the mountain area. As can be seen in the $500 \mathrm{mb}$ map in Fig. 5, the upper westerly wind had a southerly compoment. The surface weather map in Fig. 4 also shows a southerly gradient wind on these days. So the temperature in this region became higher. Fig. 7 shows the records of meteoro- logical elements during the period from $9 \mathrm{~h}$ on December 14 to $9 \mathrm{~h}$ on December 17 at these stations. The precipitation record at New Delhi shows that the rainfall was in the form of showers type. The record at Kathmandu also shows that the rainfall was concentrated in a short time. The beginning of the rainfall at about $21 \mathrm{~h}$ on December 15 was followed by thunder. The rainfall during $10 \mathrm{~h}-12 \mathrm{~h}$ on December 16 was of a more continuous type. The temperature record 


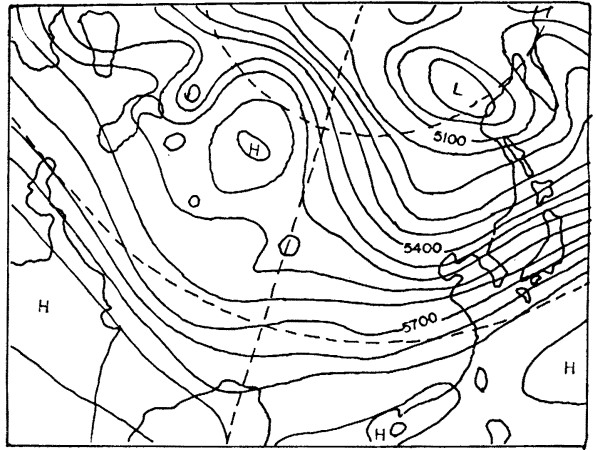

Fig. 5. $500 \mathrm{mb}$ weather map at $12 \mathrm{GMT}$, December 17, 1974.
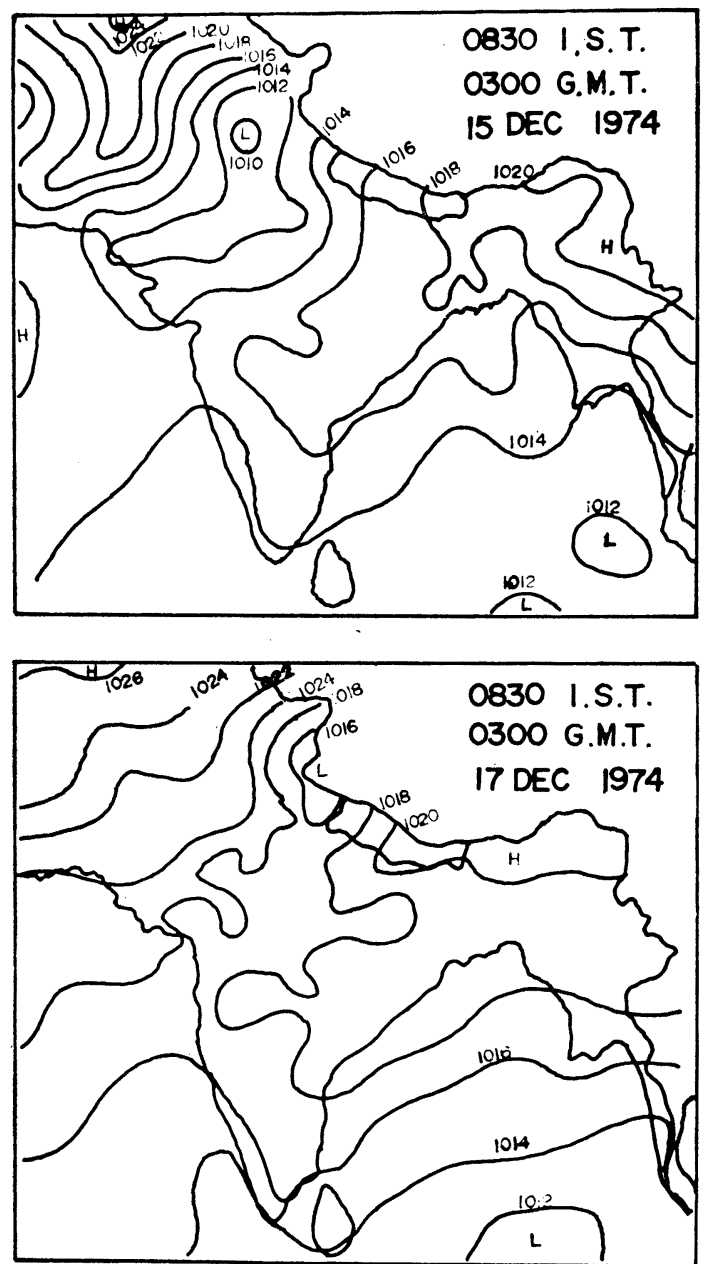

Fig. 6. Surface weather map at $0300 \mathrm{GMT}$, December 15 and 17, 1974.

of Kathmandu shows that the diurnal variation was slight on December 16. The humidity record also indicates cloudiness on the same day. The
Shyanboche humidity record shows that the humidity remained at $100 \%$ from $12 \mathrm{~h}$ on December 14 to $6 \mathrm{~h}$ on December 17 .

The record at our station at Lhajung is quite interesting. Since the temperature was almost constant, the change in humidity can be considered as being due to vapor advection. This can be easily seen when comparing the humidity record at Kathmandu with that at Lhajung. J. Inoue (1976) discusses this problem statistically. At Kathmandu, the humidity curve and the temperature curve are in the opposite sense, so the humidity is high during the night time. On the contrary, the humidity is usually high in the afternoon at Lhajung. From $13 \mathrm{~h}$ on December 15 to $16 \mathrm{~h}$ on December 16 and from $11 \mathrm{~h}$ to $19 \mathrm{~h}$ on December 16, the humidity was almost $100 \%$, and this means that it was cloudy with occasional snow during all these periods.

\section{Conclusion}

As described in the previous sections, the synoptic pattern for August and December 1974 was analyzed. In summer, the vapor supply to Nepal area is by the southerly monsoon wind. The monsoon wind originates from far south and may be from the southern hemisphere, but the intensity of the wind near Nepal is greately influenced by the local west-east pressure gradient. Especially, the influence of the disturbances in northern Pakistan and near the northern coast of the Bay of Bengal is very important. These disturbances develop when the Tibetan High moves to the north or weakens. The daily or several days mean position of the trough line in the middle latitudes wave is also important. The disturbances in the Bay of Bengal develop when the trough line is along the $90^{\circ} \mathrm{E}$ meridian, and the Pakistan disturbances develop when the trough line is along the $70^{\circ} \mathrm{E}$ meridian. When the monsoon brings warm and moist air into the plain area in Nepal, the atmospheric stratification in this area becomes unstable and thunderstorms frequently occur. Therefore, the rainfall area is not so large. However, in the high mountain area, drizzle occurs every day due to valley winds. When the monsoon wind becomes strong, the valley wind in these high mountains also become strong and the amount of precipitation increases. In higher areas, the precipitation is not rainfall, but snowfall. 
Table 2. Meteorological data during December 14-17, 1974

(A) New Delhi

\begin{tabular}{c|l|l|l}
\hline \multirow{2}{*}{ Date } & \multicolumn{2}{|c|}{ Temperature $(8 \mathrm{~h} 30 \mathrm{~m})$} & \multicolumn{1}{c}{ Precipitation } \\
\cline { 2 - 4 } & $\max$ & $\min$ & \\
\hline 14 & $2{ }^{\circ} \mathrm{C}$ & $8^{\circ} \mathrm{C}$ & - \\
15 & 23.5 & 11 & $1.5 \mathrm{~mm}(7 \mathrm{~h}-8 \mathrm{~h}, 15 \mathrm{th})$ \\
16 & 18 & 11 & - \\
17 & 18 & 12 & $5.0 \mathrm{~mm}$ (concentrate in $2 \mathrm{~h}-3 \mathrm{~h}, 17 \mathrm{th})$ \\
\hline
\end{tabular}

(B) Kathmandu

\begin{tabular}{|c|c|c|c|c|c|c|}
\hline \multirow{2}{*}{ Date } & \multicolumn{3}{|c|}{ Temperature } & \multicolumn{2}{|r|}{ Wind } & \multirow{2}{*}{$\frac{\text { Precipitation }}{\mathrm{mm}}$} \\
\hline & $8 \mathrm{~h}{ }^{40} \mathrm{C}$ & $\underset{{ }^{\circ} \mathrm{C}}{\operatorname{Max}}$ & ${ }^{\circ} \mathrm{Cin}$ & $\begin{array}{c}8 \mathrm{~h} 40 \mathrm{~m} \\
\mathrm{~m} / \mathrm{s}\end{array}$ & $\operatorname{Max} \mathrm{m} / \mathrm{s}$ & \\
\hline 14 & 3. 0 & 16.0 & 1.2 & calm & W $9.0(16 \mathrm{~h} 00 \mathrm{~m}, 14 \mathrm{th})$ & - \\
\hline 15 & 5.0 & 15.0 & 3.1 & calm & ESE $7.0(13 \mathrm{~h} 30 \mathrm{~m}, 15$ th $)$ & 3. $0(20 \mathrm{~h} 30 \mathrm{~m}-23 \mathrm{~h} 48 \mathrm{~m}, 15 \mathrm{th})$ \\
\hline 16 & 6.2 & 15. 0 & 5.0 & W 3.0 & E $6.0(16 \mathrm{~h} 30 \mathrm{~m}, 16 \mathrm{th})$ & 5. $0(11 \mathrm{~h} 30 \mathrm{~m}-14 \mathrm{~h} 00 \mathrm{~m}, 16 \mathrm{th})$ \\
\hline 17 & 4.0 & 9.0 & 2.0 & E 1.0 & SW $5.0(17 \mathrm{~h} 00 \mathrm{~m}, 17 \mathrm{th})$ & 2. $8(17 \mathrm{~h} 30 \mathrm{~m}-20 \mathrm{~h} 00 \mathrm{~m}, 17$ th $)$ \\
\hline
\end{tabular}

(C) Shyanboche Air Port

\begin{tabular}{|c|c|c|c|c|c|c|c|c|}
\hline \multirow{2}{*}{ Date } & \multicolumn{3}{|c|}{ Temperature } & \multirow{2}{*}{$\begin{array}{l}\text { Relative } \\
\text { Humidity } \\
\%\end{array}$} & \multirow{2}{*}{$\begin{array}{l}\text { Dew } \\
\text { Point } \\
{ }^{\circ} \mathrm{C}\end{array}$} & \multirow{2}{*}{$\begin{array}{l}\text { Wind } \\
\mathrm{m} / \mathrm{s}\end{array}$} & \multirow{2}{*}{$\begin{array}{c}\text { Visibility } \\
\text { km }\end{array}$} & \multirow{2}{*}{$\begin{array}{c}\text { Precipitation } \\
\mathrm{mm}\end{array}$} \\
\hline & ${ }^{8 \mathrm{~h} 40 \mathrm{~m}}$ & ${ }^{\operatorname{Max}} \mathrm{C}$ & ${ }^{\circ} \mathrm{Cin}$ & & & & & \\
\hline 14 & -4.8 & -3.4 & -10.9 & 78 & -8.1 & calm & 4.0 & - \\
\hline 15 & -6.2 & -0.8 & -8.7 & 100 & -6.2 & calm & 0.1 & *6. 9 \\
\hline 16 & -5.0 & -3.9 & -6.8 & 100 & -5.0 & $\mathrm{~N} 0.8$ & 0.6 & $* 4.1$ \\
\hline 17 & -6.8 & -3.9 & -10.8 & 88 & -8.3 & SW 0.5 & 8. 0 & * 7.0 \\
\hline
\end{tabular}

(D) Thyanboche

\begin{tabular}{|c|c|c|c|c|c|c|c|}
\hline & \multirow{2}{*}{ Date } & \multicolumn{4}{|c|}{ Temperature } & \multirow{2}{*}{ Precipitation } & \multirow{2}{*}{ Weather } \\
\hline & & Dry Bulb & Wet Bulb & $\operatorname{Max}$ & Min & & \\
\hline 14 & $\begin{array}{r}8 \mathrm{~h} 40 \mathrm{~m} \\
11 \mathrm{~h} 40 \mathrm{~m}\end{array}$ & $-6.3^{\circ} \mathrm{C}$ & $-2.7^{\circ} \mathrm{C}$ & $\begin{aligned} & 2.0^{\circ} \mathrm{C} \\
- & 6.6\end{aligned}$ & $\begin{array}{l}-13.8^{\circ} \mathrm{C} \\
-1 \text { I. } 0\end{array}$ & - & Fair \\
\hline 15 & $\begin{array}{r}8 \mathrm{~h} 40 \mathrm{~m} \\
11 \mathrm{~h} 40 \mathrm{~m}\end{array}$ & -6.8 & -1.4 & $\begin{array}{r}7.0 \\
-4.3\end{array}$ & $\begin{array}{l}-13.0 \\
-10.0\end{array}$ & $* 4.0 \mathrm{~mm}$ & Cloudy \\
\hline 16 & $\begin{array}{r}8 \mathrm{~h} 40 \mathrm{~m} \\
11 \mathrm{~h} 40 \mathrm{~m}\end{array}$ & -4.6 & -1.6 & $\begin{array}{l}-1.3 \\
-5.0\end{array}$ & $\begin{array}{r}-11.0 \\
-9.0\end{array}$ & $* 2.0 \mathrm{~mm}$ & Cloudy \\
\hline 17 & $\begin{array}{r}8 \mathrm{~h} 40 \mathrm{~m} \\
11 \mathrm{~h} 40 \mathrm{~m}\end{array}$ & -6.4 & -7.5 & $\begin{array}{l}-4.0 \\
-8.3\end{array}$ & $\begin{array}{l}-13.6 \\
-11.0\end{array}$ & (unknown) & Cloudy \\
\hline
\end{tabular}

(E) Lhajung

\begin{tabular}{c|c|c|c|c|c|c|c}
\hline \multirow{2}{*}{ Date } & \multicolumn{3}{|c|}{ Temperature } & \multicolumn{3}{c|}{ Wind } & \multirow{2}{*}{ Precipitation } \\
\cline { 2 - 7 } & Mean & Max & Min & Mean & \multicolumn{2}{c}{ Max } & \\
\hline 14 & $-7.7^{\circ} \mathrm{C}$ & $0.3^{\circ} \mathrm{C}$ & $-14.6^{\circ} \mathrm{C}$ & $4.3 \mathrm{~m} / \mathrm{s}$ & $6.7 \mathrm{~m} / \mathrm{s}(\mathrm{S})$ & $0.0 \mathrm{~mm}$ \\
15 & -9.0 & -4.4 & -11.9 & 4.4 & 7.1 & $(\mathrm{~S})$ & $* 3.2$ \\
16 & -9.7 & -2.2 & -11.2 & 5.0 & 5.2 & $(\mathrm{~N})$ & $* 1.3$ \\
17 & -9.0 & -3.4 & -14.7 & 3.8 & 6.2 & $(\mathrm{~N})$ & $* 3.7$ \\
\hline
\end{tabular}




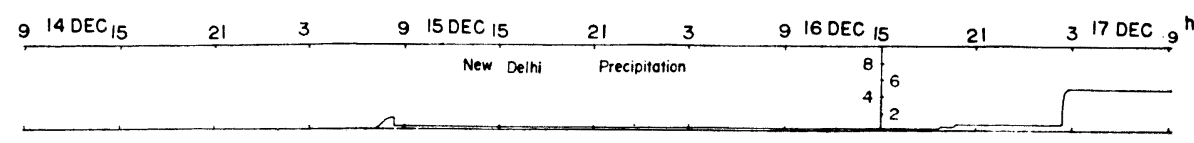

\begin{tabular}{|c|c|c|c|c|c|c|}
\hline $9^{14 D E C}$ & 21 & $9^{15 D E C}$ & 21 & $9^{16 D E C}$ & 21 & 17 DEC $_{9}$ \\
\hline Kathmandu & Precipitation & & & & & \\
\hline
\end{tabular}
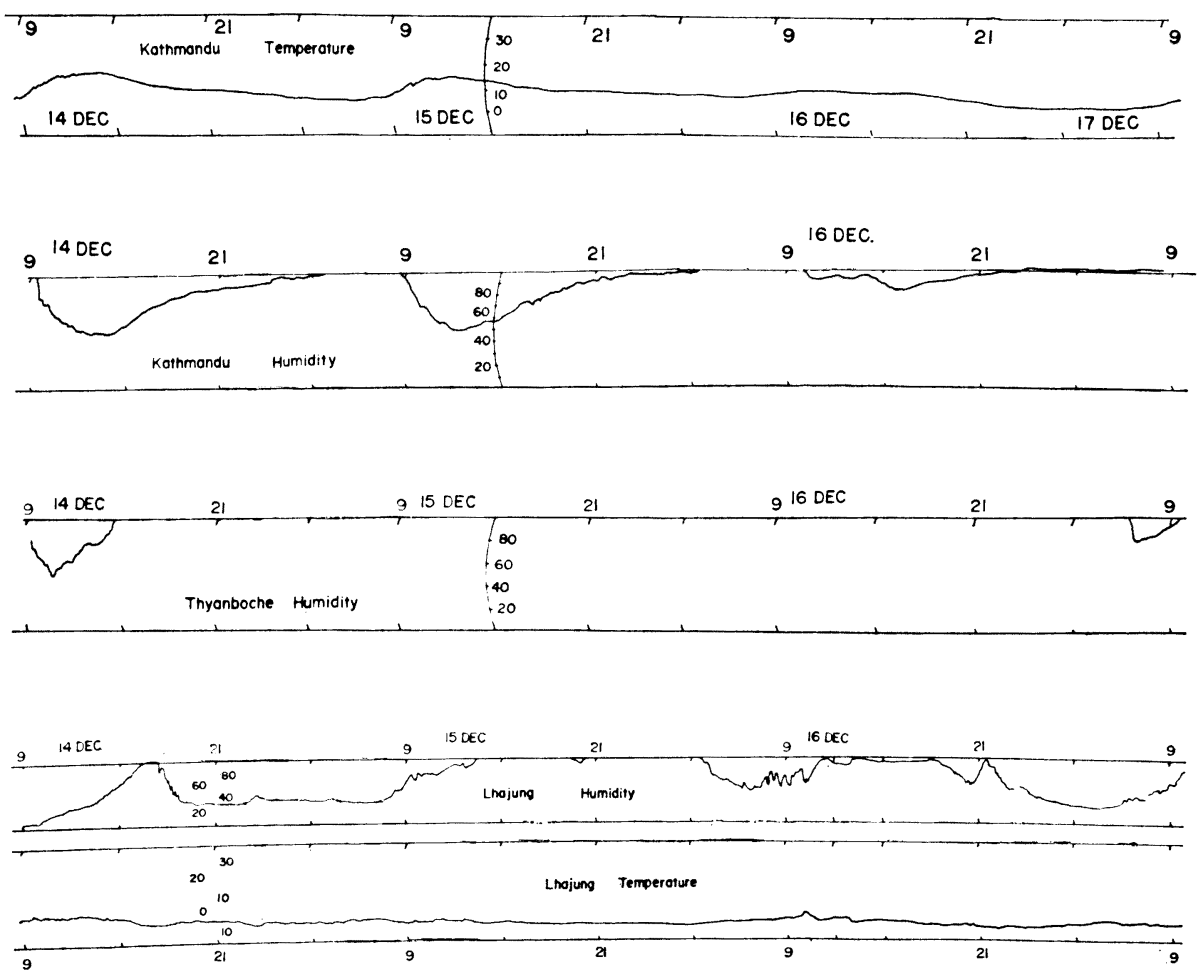

Fig. 7. Copies of the self-recording chart for $9 \mathrm{~h}$ on December 14 to $9 \mathrm{~h}$ on December 17, 1974.

When winter comes, after long dry autumn, the jet stream in middle latitudes becomes strong and the position of the jet stream axis moves to the south. When a blocking pattern develops over the Asian continent to the north of India, a branch of the jet stream moves to the southern side of the Himalayas and the upper level wind has a southerly component over Nepal. In such a case, the southerly component of the wind brings relatively warm and moist air into Nepal. The case of December 15-17, 1974 was an example of this type. In this case showery precipitation occurs in the plain area in Nepal as in summer, but in the higher mountain area the valley wind developed and consequently continuous snowfall occurred.

When a blocking pattern develops north of the Himalayas, a strong confluence of the polar and the subtropical jet stream branches occurs over Japan, and the southwesterly wind becomes strong. In such a case severe winter conditions prevail over Japan. 


\section{Acknowledgements}

Weather data at New Delhi and Calcutta were kindly provided by Meteorological Office of India.

\section{References}

Hagen, T. (1961): Nepal, Kummerly \& Frey, Berne. Inoue, J. (1976): Climate of Khumbu Himal, in this issue.

Koteswaram, P. (1973): The Weather over the Himalayas.

Kraus, H. (1966): Das Klima von Nepal Khumbu Himal, Band 1, Forschungsunternehmens Nepal Himalaya, München, pp. 301-321.
Malla, U.M. (1968): Climatic Elements and Seasons in Kathmandu Valley, The Himalayan Review 21st International Geographical Congress Special Issue, Nepal Geographical Society, pp. 53-77.

Oi, S. (1969): The weather over the Himalayas, Iwa to Yuki, 14, pp. 100-109.

Osada, M. (1972): The Japanese Mount Everest Expedition 1969-1970.

Raghavan, K. (1972): On Weather Analysis and Forecasting over the Indo-Tibetan Region, Journal of Applied Meteorology, 11, pp. 227-233.

Yasunari, T. (1976 a): Seasonal weather variation in Khumbu Himal, in this issue.

Yasunari, T. (1976 b): Spectral Analysis of Monsoonal Precipitation in Nepal Himalaya, in this issue. 